\title{
The Effect of Iranian EFL Learners' Awareness of Reading Comprehension Strategies on Their Motivation to Read
}

\author{
Poroushat Jamshidi (Corresponding author) \\ M.A. student \\ Dept. of English, Science and Research Branch, Islamic Azad University, Tehran, Iran \\ Tel: 98-91-1216-6300_E-mail:po_j89@yahoo.com \\ Dr. Masoud Yazdani Moghaddam \\ Garmsar Branch, Islamic Azad University \\ Dept. of English, Science and Research Branch, Islamic Azad University, Tehran, Iran \\ Tel: 98-91-2130-4816 E-mail: mym1300@gmail.com
}

Received: December 6, 2012 Accepted: December 31, 2012 Published: January 4, 2013

doi:10.5296/ijele.v1i1.2995 URL: http://dx.doi.org/10.5296/ijele.v1i1.2995

\begin{abstract}
Although it is generally clear that reading plays a significant role in a language, reading comprehension remains a young field that merits greater research attention. Moreover, knowledge about reading comprehension regarding learning strategies has been devoted to those involving in listening, writing and speaking. Concerning the above mentioned points and the importance of reading, the current study aims at investigating whether the awareness of reading comprehension strategies and instructing reading strategies have any effect on Iranian EFL learners' motivation and their comprehension abilities. To this end, 62 female learners of intermediate level were selected from among 100 learners. They were EFL learners studying English at Kish language institute. The participants were between the ages of 18 to 30 years old. There were experimental ( 3 classes, 37 students) and control groups (2 classes, 25 students), which were decided upon based on proficiency test. All subjects in the experimental group were exposed to reading strategies while working on reading texts of their course books. On the other hand, in control group, the reading texts were used without pointing to any of reading strategies and just focusing on the outcome of reading. A pre-test
\end{abstract}




\section{Macrothink}

International Journal of English Language Education

ISSN 2325-0887 2013, Vol. 1, No. 1

of reading comprehension and a parallel post-test were given to subjects. At the beginning and almost at the end of the semester Schmidt et al.'s (1996) motivation questionnaire was administered to both groups to investigate their progress in their motivation at the end of the study. The results revealed that the awareness of reading comprehension strategies affect Iranian EFL learners' motivation and reading comprehension abilities.

Keywords: English language learners, Reading, Reading comprehension strategies, Motivation 


\section{Introduction}

During the last few decades, there has been a marked shift in the focus of language instruction towards the needs of individual learners and their responsibilities in learning. They are becoming less dependent on the language teacher and more autonomous to diagnose their own learning strengths and weaknesses (Tarone \& Yule, 1989, cited in Cohen, 1998). Extensive investigation has shown the importance of language learning strategies (Wenden, 1987). The change that has taken place increases the use of language learning strategies as a great help in making learning more efficient and effective (Oxford \& Crookall, 1989).

\subsection{Reading Strategies}

Reading is a complex cognitive activity requiring a set of processes and strategies. Reading is defined as a communicative act or the transformation of text into discourse by an individual; accordingly both text and context need to be taken into account in any description of reading and when a reader recreates discourse from a written text he performs the act of reading (Grellet, 1981).

Vandergrift (2003) believed that guiding learners through the process of reading not only provides them with the knowledge through which they can become more skilled readers, but also motivates them and puts them in control of their learning.

Cohen (1998) asserted that the strategy training movement is predicated on the assumption that if learners are conscious and aware and become responsible for the selection, use, and evaluation of their learning strategies, they will become more successful language learners by improving their use of class time, becoming more aware of their individual learning needs, and taking more responsibility for their own language learning. Strategy training can thus be used to help learners achieve learners' autonomy, as well as linguistic autonomy.

\subsection{Motivation}

According to Bandura (1986), motivation is a goal-oriented behavior inspired and sustained by exceptions concerning the anticipated outcomes of actions. Motivation influences how and why people learn as well as their performances (Pintrich and Schunk, 1996). Motivation is viewed as a dynamic, situated and social construct (e.g., Dornyei, 1998), and closely related to learners' identity construction.

Research has shown that motivation directly influences how often learners use L2 learning strategies, how much input they receive in the language being learned, and how high their general proficiency level becomes (Dornyei, 1998).

Furthermore, as Oxford and Shearin (1994) noted, motivation has been widely accepted by both teachers and researches as one of the key factors that influences the rate and success of L2 learning. Therefore, it is extremely important for L2 learning and it is crucial to understand what learners' motivations are.

Because of the above -mentioned importance of motivation, it has been the target of a great deal of research during past decades. According to Norris-Halt (2001), until the 1990s, 
researches on motivation had been largely dominated by a social psychological approach, inspired by the influential work of Gardner and Lambert (1972).

\section{Purpose of the Study}

As Nunan (1999) noted, there is a need to develop the learners' awareness of the process underlying their own learning strategies; so that learners will not only become better readers, but also more effective language learners and more motivated ones. Gardner and Lambert (1972) emphasize the priority of motivation among factors, which directly affects the learners' active personal involvement in language learning. Therefore, highly motivated learners will take up any learning opportunity offered by the classroom and involve themselves in learning the language.

To do so this study is intended for investigating the following research question:

1. Does Iranian EFL learners' awareness of reading comprehension strategies affect their motivation to read?

2. Does Iranian EFL learners' awareness of reading comprehension strategies affect their reading comprehension ability?

\section{Methodology}

\subsection{Participants}

100 female learners of English as a second language participated in the current study. They attended 14 sessions of English classes at Kish language institute. The mean age of the participants of the study was about 24, ranging from 18 to 30 while all the participants shared the same level of language proficiency. To measure their proficiency, Cambridge Preliminary Test (PET) was applied. The participants whose scores were close to the mean, i.e. one standard deviation above and below the mean, were selected. This resulted in the selection of 62 participants for the study.

\subsection{Instrument}

A set of instruments were used in this study which are as follows: a standard proficiency test (PET) to homogenize participants, a thinking aloud protocol to assess the participants' awareness of reading strategies, a reading comprehension test, and a motivation questionnaire (Schmidt, Boraie, and Kassabgys' (1996).

\subsection{Data Collection}

The subjects were randomly assigned into experimental (3 classes) and control groups (2 classes). At the beginning of the semester a PET reading comprehension test was given to both groups to investigate the extent of their knowledge of intended reading comprehension strategies and Schmidt et al.'s (1996) motivation questionnaire was administered to investigate if they would progress in their motivation at the end of the study. The control group $(\mathrm{N}=25)$, on the other hand, only studied the required course book of the institute.

During the 10-week-treatment period, the participants were explicitly instructed to embrace 
some reading strategies, consisting of cognitive strategies, meta-cognitive strategies, socio-affective strategies, and one memory strategy.

On the other hand, in the control group, the similar reading texts were used without directing the participants' attention to any of the reading strategies so that they just focused on the outcome of reading.

At the end of the treatment period, a post-test of reading comprehension test was administered to know the influences of awareness of reading comprehension strategies on the learners' reading comprehension abilities. Schmidt et al.'s motivation questionnaire (1996) was again administered to both experimental and control groups to investigate any possible increase in students' motivation.

\subsection{Data Analysis}

The collected data were fed into SPSS. To come up with reasonable answers to the research questions MANOVA and a number of T-tests were run respectively to determine the effects of independent variables on the dependent ones.

\section{Results}

The results of the independent sample t-test $(\mathrm{t}(60)=.26, \mathrm{P}=.791>.05, \mathrm{R}=.03$; representing a weak effect size) indicates a non-significant difference between the mean scores of the two groups on the pretest of reading comprehension. Thus it can be concluded that the experimental and control groups were homogenous in terms of the reading comprehension ability prior to the administration of the reading comprehension awareness strategies.

Table 1. Independent t-test Pretest of Reading Comprehension by Groups

\begin{tabular}{|c|c|c|c|c|c|c|c|c|c|}
\hline & \multicolumn{2}{|c|}{$\begin{array}{l}\text { Levene's Test } \\
\text { for Equality } \\
\text { of Variances }\end{array}$} & \multicolumn{7}{|c|}{ t-test for Equality of Means } \\
\hline & \multirow[t]{2}{*}{$\mathrm{F}$} & \multirow[t]{2}{*}{ Sig. } & \multirow[t]{2}{*}{$\mathrm{T}$} & \multirow[t]{2}{*}{$\mathrm{df}$} & \multirow[t]{2}{*}{$\begin{array}{c}\text { Sig. } \\
\text { (2-tailed }\end{array}$} & \multirow[t]{2}{*}{$\begin{array}{c}\text { Mean } \\
\text { Difference }\end{array}$} & \multirow[t]{2}{*}{$\begin{array}{l}\text { Std. Error } \\
\text { Difference }\end{array}$} & \multicolumn{2}{|c|}{$\begin{array}{l}95 \% \text { Confidence } \\
\text { Interval of the } \\
\text { Difference }\end{array}$} \\
\hline & & & & & & & & Lower & Upper \\
\hline $\begin{array}{c}\text { Equal variances } \\
\text { assumed }\end{array}$ & 1.49 & .226 & .266 & 60 & .791 & .232 & .872 & -1.512 & 1.977 \\
\hline $\begin{array}{l}\text { Equal variances } \\
\text { not assumed }\end{array}$ & & & .260 & 46.99 & .796 & .232 & .895 & -1.568 & 2.033 \\
\hline
\end{tabular}




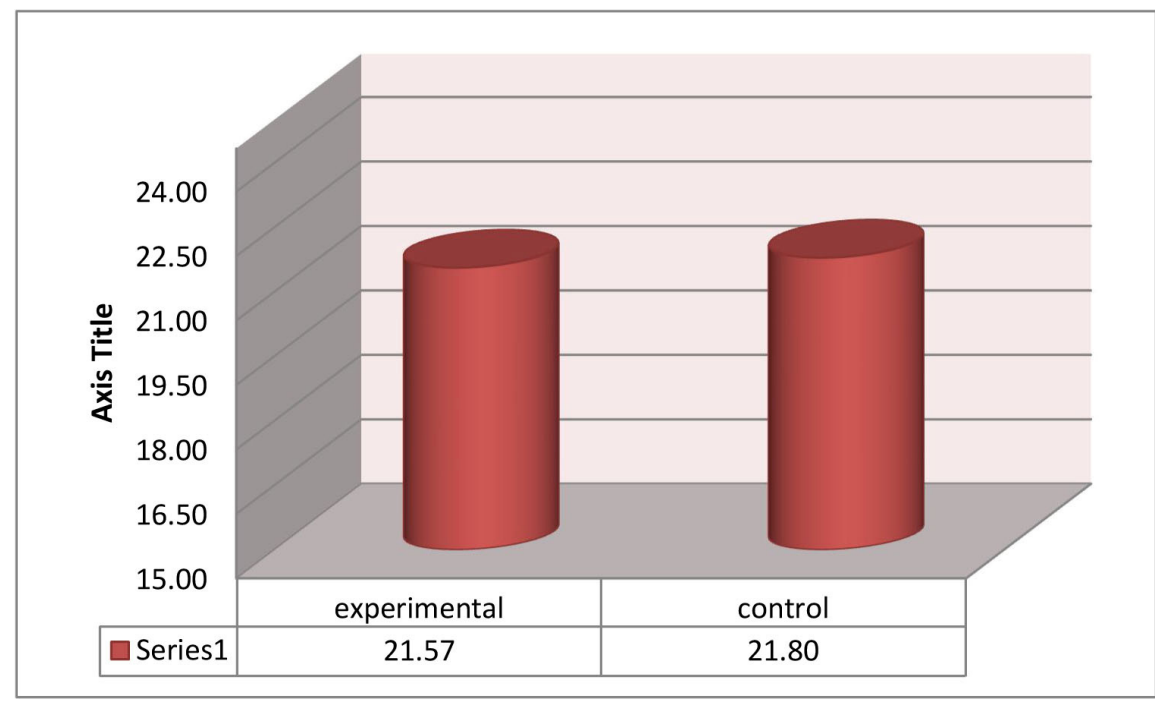

Figure 1. Pretest of Reading Comprehension by Groups

Another independent sample t-test was run to compare the mean scores of the experimental and control groups on the pretest of motivation prior to the administration of the reading comprehension awareness strategies to the experimental group.

Table 2. Independent t-test Pretest of Motivation by Groups

\begin{tabular}{|c|c|c|c|c|c|c|c|c|c|}
\hline & \multicolumn{9}{|c|}{$\begin{array}{l}\text { Levene's Testt-test for Equality of Means } \\
\text { for Equality of } \\
\text { Variances }\end{array}$} \\
\hline & \multirow[t]{2}{*}{$\mathrm{F}$} & \multirow[t]{2}{*}{ Sig. } & \multirow[t]{2}{*}{$t$} & \multirow[t]{2}{*}{ df } & \multirow[t]{2}{*}{$\begin{array}{l}\text { Sig. } \\
\text { (2-tailed) }\end{array}$} & \multirow[t]{2}{*}{$\begin{array}{l}\text { Mean } \\
\text { Difference }\end{array}$} & \multirow[t]{2}{*}{$\begin{array}{l}\text { Std. Err } \\
\text { Difference }\end{array}$} & \multicolumn{2}{|c|}{$\begin{array}{l}95 \% \text { Confidence } \\
\text { Interval of the } \\
\text { Difference }\end{array}$} \\
\hline & & & & & & & & Lower & Upper \\
\hline $\begin{array}{l}\text { Equal } \\
\text { variances } \\
\text { assumed }\end{array}$ & .115 & .736 & .617 & 760 & .540 & .156 & .253 & -.351 & .663 \\
\hline $\begin{array}{l}\text { Equal } \\
\text { variances not } \\
\text { assumed }\end{array}$ & & & .631 & 55.43 & .531 & .156 & .248 & -.340 & .653 \\
\hline
\end{tabular}

As it is obvious in the table the results indicate a non-significant difference between the mean scores of the two groups on the pretest of motivation ( $\mathrm{t}(60)=.61, \mathrm{P}=.540>.05, \mathrm{R}=.07$; representing a weak effect size). Thus it can be concluded that the experimental and control 
groups were also homogenous in terms of their motivation.

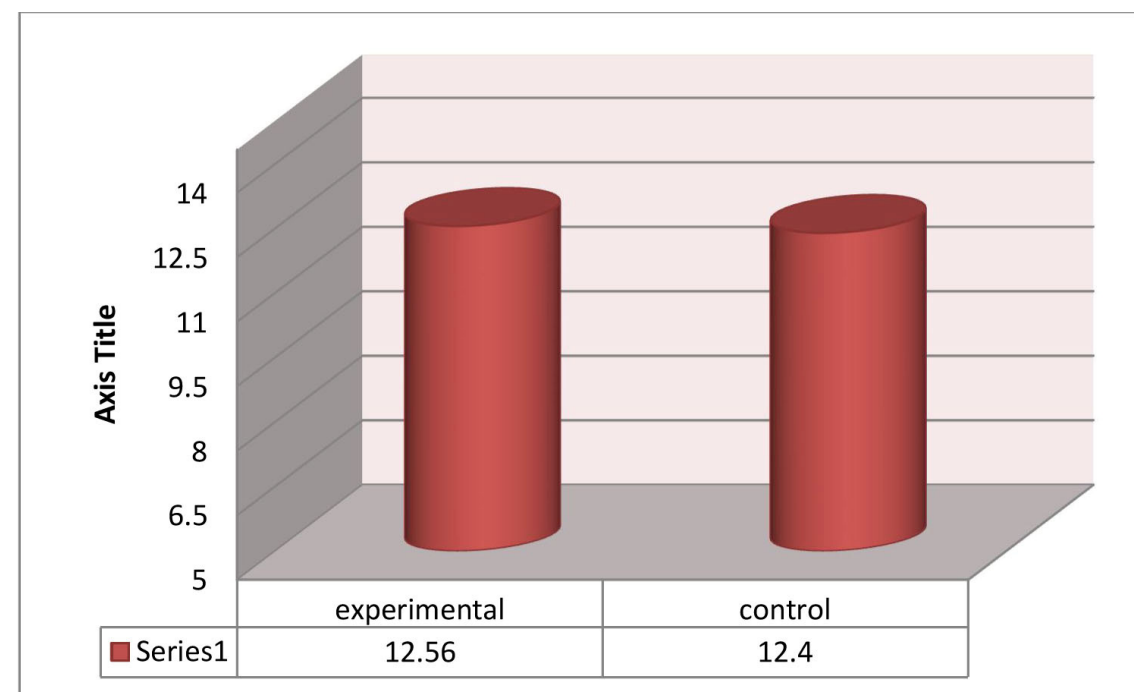

Figure 2. Pretest of Motivation by Groups

In order to answer the first research question, after the administration of the reading comprehension awareness strategies to the experimental group an independent sample t-test was run to compare the mean scores of the experimental group to that of control group on the posttest of reading motivation. As displayed in Table 3, the mean scores of the experimental and control groups on the posttest of reading motivation are 18.22 and 13.19.

Table 3. Posttest of Reading Motivation by Groups

\begin{tabular}{|l|c|c|c|c|}
\hline Groups & $\mathbf{N}$ & Mean & Std. Deviation & Std. Error Mean \\
\hline Experimental & 37 & 18.22 & 1.046 & .172 \\
\hline Control & 25 & 13.19 & 1.022 & .204 \\
\hline
\end{tabular}

The results of the independent $\mathrm{t}$-test $(\mathrm{t}(60)=18.74, \mathrm{P}=.000<.05, \mathrm{R}=.92$; representing a strong effect size) indicates significant difference between the mean scores of the two groups on the posttest of reading motivation. Thus it can be concluded that the first null-hypothesis as Iranian EFL learners' awareness of reading comprehension strategies does not affect their motivation for reading is rejected. The subjects in the experimental group, after being aware of reading comprehension strategies, significantly improved their motivation for reading. 
Table 4. Independent t-test Posttest of Reading Motivation by Groups

\begin{tabular}{|c|c|c|c|c|c|c|c|c|c|}
\hline & $\begin{array}{l}\text { Leve } \\
\text { Test } \\
\text { Equa } \\
\text { of } \\
\text { Varia } \\
\end{array}$ & $\begin{array}{l}\text { ne's } \\
\text { for } \\
\text { lity } \\
\text { nces }\end{array}$ & $t$-test fo & or Equal & lity of Mea & ans & & & \\
\hline & $\mathrm{F}$ & Sig. & $\mathrm{T}$ & df & $\begin{array}{l}\text { Sig. } \\
\text { (2-tailed) }\end{array}$ & $\begin{array}{l}\text { Mean } \\
\text { Difference }\end{array}$ & $\begin{array}{l}\text { Std. Error } \\
\text { Difference }\end{array}$ & $\begin{array}{l}95 \% \\
\text { Confide } \\
\text { Interva } \\
\text { Differe }\end{array}$ & $\begin{array}{l}\text { ence } \\
\text { l of the } \\
\text { ance }\end{array}$ \\
\hline & & & & & & & & Lower & Upper \\
\hline $\begin{array}{l}\text { Equal variances } \\
\text { assumed }\end{array}$ & .133 & .717 & 18.74 & 60 & .000 & 5.029 & .268 & 4.492 & 5.565 \\
\hline $\begin{array}{l}\text { Equal variances } \\
\text { not assumed }\end{array}$ & & & 18.828 & 52.464 & .000 & 5.029 & .267 & 4.493 & 5.565 \\
\hline
\end{tabular}

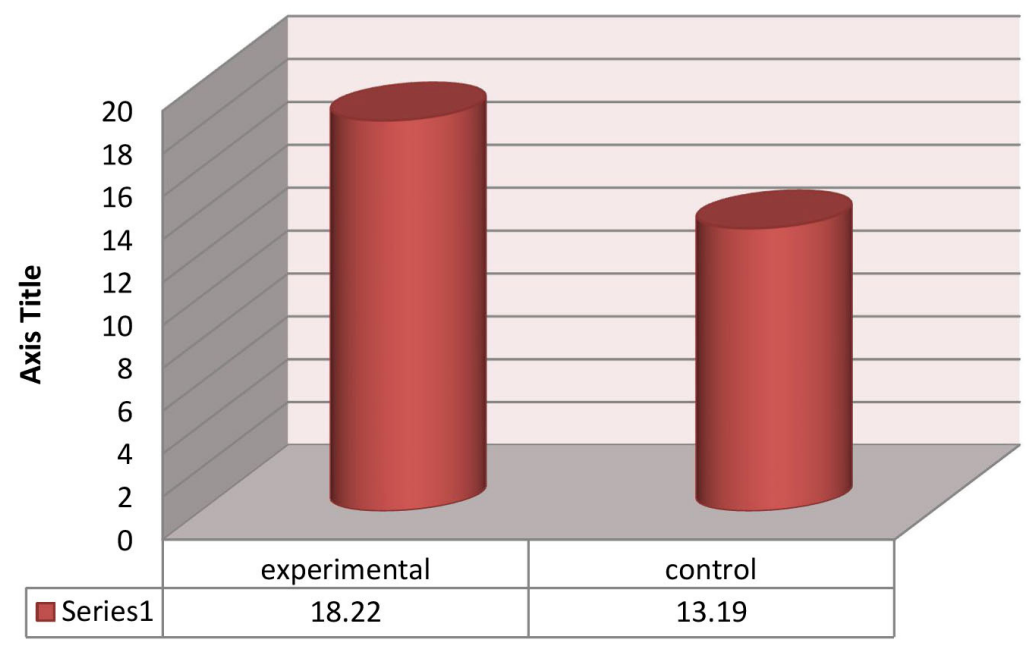

Figure 3. Posttest of Reading Motivation by Groups

When a significant difference is observed in two groups in terms of their motivation further analysis is conducted on the subscales of motivation in two groups. So a multivariate analysis of variances (MANOVA) is run to compare the experimental and control groups' mean scores on the seven components of motivation measured after the administration of reading strategies to the former group. Table 5 displays the mean scores for the experimental and control groups on the seven components of posttest of motivation. The experimental group shows higher mean scores across all of the seven components of motivation. 
Table 5. Descriptive Statistics Components of Posttest of Motivation

\begin{tabular}{|c|c|c|c|c|}
\hline & GROUPS & Mean & Std. Deviation & $\mathrm{N}$ \\
\hline \multirow{2}{*}{ Posttest of Intrinsic } & experimental & 19.76 & 2.216 & 37 \\
\hline & control & 14.72 & 2.283 & 25 \\
\hline \multirow{2}{*}{ Posttest of Extrinsic } & experimental & 19.74 & 2.039 & 37 \\
\hline & control & 10.84 & 1.857 & 25 \\
\hline \multirow{2}{*}{\begin{tabular}{|ll} 
Posttest of & Personal \\
Psychological Needs &
\end{tabular}} & experimental & 21.78 & 2.110 & 37 \\
\hline & control & 12.68 & 1.887 & 25 \\
\hline \multirow{2}{*}{$\begin{array}{l}\text { Posttest of Expectations, } \\
\text { Locus of Control }\end{array}$} & experimental & 11.38 & 1.710 & 37 \\
\hline & control & 9.13 & 1.295 & 25 \\
\hline \multirow{2}{*}{$\begin{array}{lll}\text { Posttest of Stereotypical } \\
\text { Attitude }\end{array}$} & experimental & 19.93 & 2.825 & 37 \\
\hline & control & 18.35 & 2.620 & 25 \\
\hline \multirow{2}{*}{ Posttest of Anxiety } & experimental & 16.76 & 2.596 & 37 \\
\hline & control & 12.57 & 1.767 & 25 \\
\hline \multirow{2}{*}{$\begin{array}{lll}\text { Posttest of } & \text { Motivation } \\
\text { Strength } & & \\
\end{array}$} & experimental & 18.18 & 3.710 & 37 \\
\hline & control & 14.03 & 3.995 & 25 \\
\hline
\end{tabular}

The results of the MANOVA $(F(7,54)=90.55, \mathrm{P}=.000<.05$, Partial $\eta 2=.922$ the grouping variable can predict $92.2 \%$ of differences between mean scores) indicate significant differences between the experimental and control groups' mean scores on the seven components of motivation as measured during the posttest phase.

Table 6. MANOVA Components of Motivation by Groups

\begin{tabular}{|c|c|c|c|c|c|c|c|}
\hline \multicolumn{2}{|l|}{ Effect } & Value & $\mathrm{F}$ & $\begin{array}{l}\text { Hypothesis } \\
\text { df }\end{array}$ & Error df & Sig. & $\begin{array}{c}\text { Partial Eta } \\
\text { Squared }\end{array}$ \\
\hline \multirow{4}{*}{ Intercept } & Pillai's Trace & .996 & 2110.674 & 7 & 54 & .000 & .996 \\
\hline & Wilks' Lambda & .004 & 2110.674 & 7 & 54 & .000 & .996 \\
\hline & $\begin{array}{l}\text { Hotelling's } \\
\text { Trace } \\
\end{array}$ & 273.606 & 2110.674 & 7 & 54 & .000 & .996 \\
\hline & $\begin{array}{ll}\text { Roy's Largest } \\
\text { Root }\end{array}$ & 273.606 & 2110.674 & 7 & 54 & .000 & .996 \\
\hline \multirow{4}{*}{ GROUPS } & Pillai's Trace & .922 & 90.559 & 7 & 54 & .000 & .922 \\
\hline & Wilks' Lambda & .078 & 90.559 & 7 & 54 & .000 & .922 \\
\hline & $\begin{array}{l}\text { Hotelling's } \\
\text { Trace }\end{array}$ & 11.739 & 90.559 & 7 & 54 & .000 & .922 \\
\hline & \begin{tabular}{|ll} 
Roy's & Largest \\
Root & \\
\end{tabular} & 11.739 & 90.559 & 7 & 54 & .000 & .922 \\
\hline
\end{tabular}

It should be noted that the SPSS produces four F-values. In cases where all of the F-values are significant or non-significant the four statistics are the same.

Moreover, the homogeneity of variances assumption is met for the seven components of the posttest of motivation. As displayed in Table 7, the probabilities associated with the Levene's F-values are all above .05 . 
Table 7. Homogeneity of Variances Components of Posttest of Motivation

\begin{tabular}{|l|c|c|c|c|}
\hline & F & df1 & df2 & Sig. \\
\hline Posttest of Intrinsic & .252 & 1 & 60 & .617 \\
\hline Posttest of Extrinsic & 1.425 & 1 & 60 & .237 \\
\hline Posttest of Personal Psychological Needs & .195 & 1 & 60 & .660 \\
\hline Posttest of Expectations, Locus of Control & 1.709 & 1 & 60 & .196 \\
\hline Posttest of Stereotypical Attitude & .105 & 1 & 60 & .747 \\
\hline Posttest of Anxiety & 2.435 & 1 & 60 & .124 \\
\hline Posttest of Motivation Strength & .097 & 1 & 60 & .756 \\
\hline
\end{tabular}

The F-value of 90.55 indicates significant differences between the overall mean scores of the experimental and control groups on the seven components of posttests of motivation. Based on the results displayed in table 8 , it can be concluded that there are significant differences between the two groups' mean scores on each of the components of posttest on motivation. All of the probabilities associated with the F-values are lower than .05. The partial eta-squared indices range from a high of $83 \%$ to a low of $7.5 \%$.

A: There is a significant difference between the experimental and control groups' mean scores on the posttest of intrinsic motivation $(\mathrm{F}(1,60)=75.23, \mathrm{P}=.000<.05$, Partial $\eta 2$ $=.55$ the grouping variable can predict $55 \%$ of differences between mean scores on posttest of intrinsic motivation).

B: There is a significant difference between the experimental and control groups' mean scores on the posttest of extrinsic motivation $(\mathrm{F}(1,60)=305.07, \mathrm{P}=.000<.05$, Partial $\eta 2=.83$ the grouping variable can predict $83 \%$ of differences between mean scores on posttest of extrinsic motivation).

C: There is a significant difference between the experimental and control groups' mean scores on the posttest of personal motivation $(\mathrm{F}(1,60)=301.94, \mathrm{P}=.000<.05$, Partial $\eta 2=.83$ the grouping variable can predict $83 \%$ of differences between mean scores on posttest of personal motivation).

Table 8. Univariate Test

\begin{tabular}{|c|c|c|c|c|c|c|c|}
\hline \multicolumn{2}{|l|}{ Dependent Variable } & $\begin{array}{l}\text { Sum of } \\
\text { Squares }\end{array}$ & $\mathrm{df}$ & $\begin{array}{l}\text { Mean } \\
\text { Square }\end{array}$ & $\bar{F}$ & Sig. & $\begin{array}{l}\text { Partial Eta } \\
\text { Squared }\end{array}$ \\
\hline \multirow{2}{*}{ Posttest of Intrinsic } & Contrast & 378.488 & 1 & 378.488 & 75.233 & .000 & .556 \\
\hline & Error & 301.851 & 60 & 5.031 & & & \\
\hline \multirow{2}{*}{ Posttest of Extrinsic } & Contrast & 1181.260 & 1 & 1181.260 & 305.071 & .000 & .836 \\
\hline & Error & 232.325 & 60 & 3.872 & & & \\
\hline \multirow{2}{*}{$\begin{array}{l}\text { Posttest of Personal } \\
\text { Psychological Needs }\end{array}$} & Contrast & 1236.499 & 1 & 1236.499 & 301.941 & .000 & .834 \\
\hline & Error & 245.710 & 60 & 4.095 & & & \\
\hline \multirow{2}{*}{$\begin{array}{l}\text { Posttest of Expectations, } \\
\text { Locus of Control }\end{array}$} & Contrast & 75.414 & 1 & 75.414 & 31.093 & .000 & .341 \\
\hline & Error & 145.528 & 60 & 2.425 & & & \\
\hline \multirow{2}{*}{$\begin{array}{r}\text { Posttest of Stereotypical } \\
\text { Attitude }\end{array}$} & Contrast & 37.359 & 1 & 37.359 & 4.958 & .030 & .076 \\
\hline & Error & 452.081 & 60 & 7.535 & & & \\
\hline \multirow{2}{*}{ Posttest of Anxiety } & Contrast & 261.988 & 1 & 261.988 & 49.494 & .000 & 452 \\
\hline & Error & 317.602 & 60 & 5.293 & & & \\
\hline \multirow{2}{*}{$\begin{array}{r}\text { Posttest of Motivation } \\
\text { Strength }\end{array}$} & Contrast & 256.134 & 1 & 256.134 & 17.495 & .000 & 226 \\
\hline & Error & 878.411 & 60 & 14.640 & & & \\
\hline
\end{tabular}




\section{Ml Macrothink}

D: There is a significant difference between the experimental and control groups' mean scores on the posttest of expectations motivation $(\mathrm{F}(1,60)=31.09, \mathrm{P}=.000<.05$, Partial $\eta 2$ $=.34$ the grouping variable can predict $34 \%$ of differences between mean scores on posttest of expectations motivation). $\mathrm{E}$ : There is a significant difference between the experimental and control groups mean scores on the posttest of stereotypical attitude motivation $(\mathrm{F}(1,60)=$ $4.95, \mathrm{P}=.03<.05$, Partial $\eta 2=.075$ the grouping variable can predict $7.5 \%$ of differences between mean scores on posttest of stereotypical attitude motivation).

F: There is significant difference between the experimental and control groups' mean scores on the posttest of anxiety motivation $(\mathrm{F}(1,60)=49.49, \mathrm{P}=.000<.05$, Partial $\eta 2=.45$ the grouping variable can predict $45 \%$ of differences between mean scores on posttest of anxiety motivation).

G: There is a significant difference between the experimental and control groups' mean scores on the posttest of motivation strength $(\mathrm{F}(1,60)=17.49, \mathrm{P}=.000<.05$, Partial $\eta 2$ $=.22$ the grouping variable can predict $22 \%$ of differences between mean scores on posttest of motivation strength).

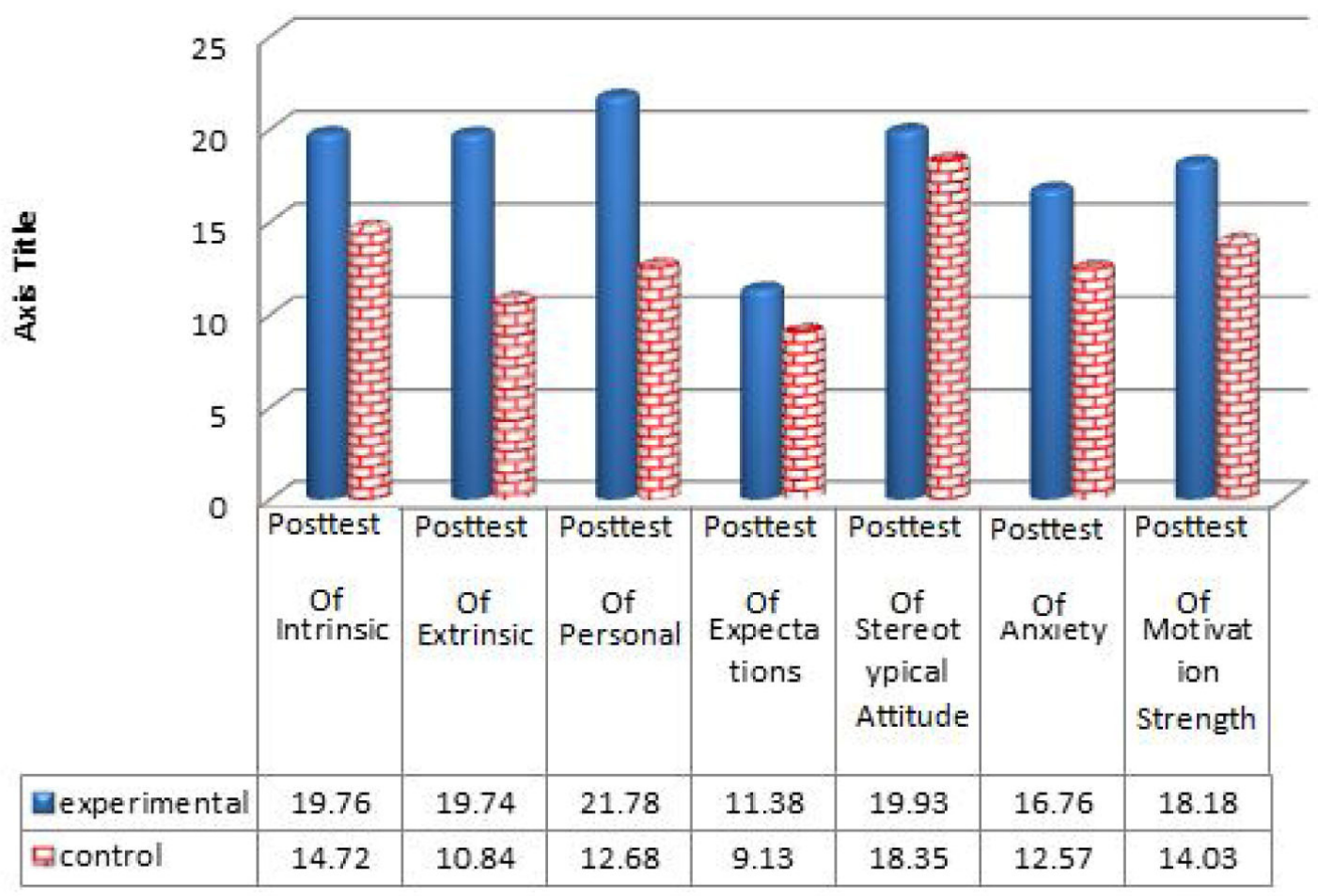

Figure 4. Components of Posttest of Motivation by Groups

In order to answer the second research question that is to compare the mean scores of reading comprehension of the experimental and control groups on the posttest another independent t-test was run. 


\section{Mll Macrothink}

Table 9. Posttest of Reading Comprehension by Groups

\begin{tabular}{|l|c|c|c|c|}
\hline Groups & $\mathrm{N}$ & Mean & Std. Deviation & Std. Error Mean \\
\hline Experimental & 37 & 24.57 & 3.185 & .524 \\
\hline Control & 25 & 22.00 & 3.014 & .603 \\
\hline
\end{tabular}

The results of the independent $\mathrm{t}$-test $(\mathrm{t}(60)=3.18, \mathrm{P}=.002<.05, \mathrm{R}=.38$; representing a moderate to strong effect size) indicates significant difference between the mean scores of the two groups on the posttest of reading comprehension. Thus it can be concluded that the second null-hypothesis as Iranian EFL learners' awareness of reading comprehension strategies does not affect their reading comprehension abilities is rejected. The subjects in the experimental group, after receiving awareness of reading comprehension strategies, significantly improved their reading comprehension ability.

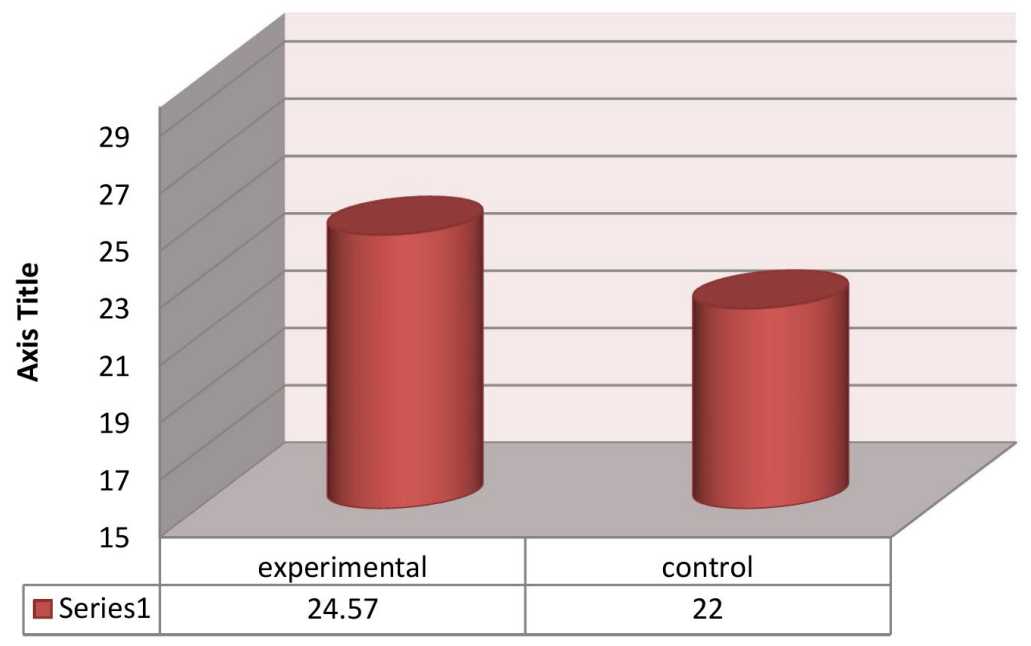

Figure 5. Posttest of Reading Comprehension by Groups

\section{Discussion}

As the analyses showed, participants in the experimental group made significant progress in their post-test with respect to motivation. Therefore, the treatment had a positive impact on the motivation of this group. This finding is in line with what Nunan (1999) hypothesized. He emphasized that incorporation of a learning strategies dimension into the curriculum enhances motivation. In the same token, Oxford and Nyikos (1989) revealed results which share commonality with the findings of the present study. The result of their study indicated that the use of appropriate strategies leads to enhanced actual and perceived proficiency, which in turn creates high self-esteem leading to strong motivation.

Research confirms that students' motivation is a key factor in successful reading. However, in 
order to support reading motivation in the classroom effectively, it is important to consider the research on reading motivation and engagement (Gambrell \& Marinak, 2009).

Guthrie and Wigfield (2000) caution that there is no 'quick fix' for increasing long-term reading motivation and engagement. His review of the research made it possible to identify 10 elements that 'set the stage' for engagement and motivation in reading: conceptual orientation, real-world instruction, autonomy support (providing students with meaningful choices), interesting texts, strategy instruction, collaborative learning, teacher involvement (e.g., interest in student knowledge, preferences, and abilities), appropriate rewards and specific praise, and evaluation aligned with instructional purposes.

A study was carried out by Mojtabaian (2004); the results of this study clearly demonstrated that awareness of learning strategies cannot foster motivation. The present study contradicted the results of the above-mentioned research by indicating the increase of motivation through applying learning strategies.

Based on the data analysis, awareness of reading comprehension strategies produces a significant effect on reading comprehension abilities of Iranian EFL learners. The findings of the present study side with and support the study done by Azizi (2003) who showed the contribution of awareness of reading strategies to reading comprehension.

Sheorey \& Mokhtari (2001), highlight the vital role of ESL learners' awareness of their reading strategies in the development of comprehension in the tasks assigned. They believe that knowing the metacognitive strategies and being aware of the strategies used may aid students to be responsive as well as to be able to construct meaning from the text. The information provided in the research could perhaps increase the awareness of reading strategies of the readers while reading and foster their understanding of the process and help them to be thoughtful, constructively responsive and strategic readers. In the present study, the researcher tried to make the learners aware of the reading strategies and it was observed that the participants in the experimental group became better strategic readers.

Contrary to the study carried out by Zhang (2001), which showed the impact of the awareness of reading strategies on the development of learners' language proficiency, the treatment process of the present study did not contribute to the improvement of the participants' proficiency level; just their reading comprehension improved.

The findings of the study are consistent with the results of previous studies by Caverly, et al. (2004), El-Hindi (1996), and Shenkman and Cukras (1986), who concluded that reading strategy instruction has positive effects on students' metacognitive strategic reading performance in developmental courses. Therefore, strategy instruction helped these students be aware of the need for recognizing and applying appropriate and effective strategies when reading. The most significant improvement for the developmental reading students in this study was in metacognitive thinking skills.

In this study, the greatest improvement was reported in terms of metacognitive strategy use, which is heartening as metacognitive thinking is closely tied to reading and literacy skills. 


\section{Macrothink}

Although the sample size in this study was fairly small and thus not generalizable to all readers, an interesting pattern emerged within the findings.

In the end, it should be remembered that "what we urgently need is to do more research on the mechanisms of learning and accompany new proposals and methods with more experimental evidence before we bring them into the classroom" (Sanchez, 2004, p. 65).

\section{Conclusion}

According to Carson \& Longhini (2002), our educational system encourages students' dependence on the teacher, leaving almost no room for learners' autonomy. The teacher plays the role of an expert and acts as the focus of all instruction, controlling every aspect of learning process. On the other hand, many students want to take a greater control over their own language development. Unfortunately, some of them lack adequate knowledge about how they can learn more effectively.

This study focused on improving the effectiveness of reading comprehension by giving responsibilities to learners for their own learning by training them to take advantage of reading comprehension strategies and by allowing them to take control of the language learning process, hoping that applying these strategies not only contributes to their comprehension but also motivates the learner to participate actively in reading comprehension activities.

\section{References}

Azizi, M. (2003). The effect of teaching reading strategies on third-grade high school student comprehension. Unpublished M.A. thesis, Science and Research Branch,Tehran, Iran.

Bandura, A. (1986). Social foundations of thought and actions: A cognitive theory: Englewood Cliffs, NJ: Prentice Hall.

Carson , J. G., \& Longhini, A. (2002). Language Learning. A Journal of Research in Language Studies, 52(2), 413-437.

Caverly, D. C., Nicholson, S. A., \& Radeliffe. R. (2004). The effectiveness of strategic reading instruction for college developmental readers. Journal of College Reading and Learning, 35(1), 25-49.

Cohen, A. D. (1998). Strategies in learning and using a second language. NY: Longman.

Dornyei, Z. (1998). Motivation in second and foreign language learning. Language Teaching, 31(3), 117-135. http://dx.doi.org/10.1017/S026144480001315X.

El-Hindi, A. E. (1996). Enhancing metacognitive awareness of college learners. Reading Horizons, 36(3), 214-230.

Gardner, R. C., \& Lambert, W.E. (1972). Attitude and motivation in second language learning. Rowley, M.A: Newbury House.

Grellet, F. (1981). Developing Reading Skills: A Practical Guide to Reading Comprehension 
Exercises. Cambridge: Cambridge University Press.

Guthrie, J., \& Wigfield, A. (2000). Engagement and motivation to read. In M. Kamil, \& P. Mosenthal, D. Pearson, R. Barr (Eds.), Handbook of reading research. Mahwah, N. J: Earlbaum, 49(7), 518-533.

Mojtabaian, M. (2004). The effect of awareness of listening comprehension strategies on motivation. Unpublished MA thesis, Science and Research Branch, Tehran, Iran.

Norris-Holt, J. (2001). Motivation as a contributing factor in second language acquisition. TESL Journal, 7(6). http://iteslj.org/Articles/Norris-Motivation.html

Nunan, D. (1999). Second language teaching and learning. Boston: Heinle \& Heinle.

Oxford, R., \& Crookall, D. (1989). Research on language learning strategies: Methods, findings and instructional issues. The Modern Language Journal, 73(4), 404-419.

Oxford, R., \& Nyikos, M. (1989). Variables affecting choice of language learning strategies by university students. The Modern language Journal, 73(3), 291-300.

Oxford, R., \& Shearin, J. (1994). Language learning motivation: Expending the theoretical framework. The Modern Language Journal, 78(1), 12-28.

Pintrich, P. R., \& Schunk, D. H. (1996). Motivation in education: Theory, research and application. Englewood Cliffs, NJ: Prentice Hall.

Schmidt, R., Boraie, D., \& Kassabgy, O. (1996). Foreign language motivation: Internal structure and external connections. In R. Oxford (Ed.), Language learning motivation: Pathways to the new century (Technical Report \#11, pp. 9-70) .Honolulu: University of Hawai'i, Second Language Teaching\& Curriculum Center.

Sheorey, R., \& Mokhtari, K. (2002). Differences in the metacognitive awareness of reading strategies among native and non-native readers. System, 29, 431-449.

Shenkman, H., \& Cukras, G. (1986). Effects of metacognitive training program on underprepared college students. In J. A. Niles, \& R. V. Lalik (Eds.), Solving problems in literacy: Learners, teachers, and researchers: Thirty-fifth Yearbook of the National Reading Conference (pp. 222-226). Chicago: National Reading Conference.

Vandergift, L. (2003b). Orchestrating strategies use: Toward a model of the skilled second language listener. Language Learning, 53(3), 463-496.

Wenden, A. L. (1987). Metacognitive knowledge and language learning. Applied linguistics, 19(4), 515-537. http://dx.doi.org/10.1111/j.1467-1770.1987.tb00585.x.

Zhang, L. J. (2001). Awareness in reading: EFL students' metacognitive knowledge of reading strategies in an acquisition-poor environment. Language Awareness, 19(4), 268-288. 


\section{Macrothink

\section{Appendix}

Schmidt et al. 's (1996) Motivation Questionnaire

\section{Schmidt et al. 's (1996) Motivation Questionnaire}

Intrinsic Motivation

1. I enjoy learning English very much.

2. Learning English is a hobby for me.

3. Learning English is a challenge that I enjoy.

4. I don't enjoy learning English, but I know that learning English is important for me.

5. I wish I could learn English in an easier way, without going to class.

Extrinsic Motivation

6. English is important to me because it will broaden my view.

7. The main reason I am taking this class is that my parents/my spouse/my supervisors want me to improve English.

8. I want to do well in this class because it is important to show my ability to my family/friends/supervisors/others.

9. Everybody in Egypt should be able to speak English.

10. Being able to speak English will add to my social status.

11. I am learning English because I want to spend a period of time in an English speaking country.

12. I want to learn English because it is useful when traveling in many countries.

13. I want to learn English because I would like to emigrate.

14. One reason I learn English is that I can meet new people and make friends in my English class.

15. I am learning English to become more educated.

16. I need to be able to read textbooks in English.

17. The main reason I need to learn English is to pass examination.

18. If I learn English better, I will be able to get a better job.

19. Increasing my English proficiency will have financial benefits for me.

20. If I can speak English I will have a marvellous life.

Personal Goals

21. I really want to learn more English in this class than I have done in the past.

22. It is important to me to do better than the other students in my class.

23. My relationship with the teacher in this class is important to me.

24. One of the most important things in this class is getting along with the other students.

25. This class is important to me because if I learn English well, I will be able to help my children learn English.

Expectancy/Control Components

26. This English class will definitely help me improve my English. 
27. If I do well in this course, it will be because I try hard.

28. I expect to do well in this class because I am good at learning English.

29. If I don't do well in this class, it will be because I don't try hard enough.

30. If I don `t do well in this class, it will be because I don't have much ability for learning English.

31. If I learn a lot in this class, it will be because of the teacher.

32. If I do well in this class, it will be because this is an easy class.

33. If I don't learn well in this class, it will be mainly because of the teacher.

34. If I don 't do well in this class, it will be because the class is too difficult.

Attitudes

35. Americans are very friendly people.

36. The English are conservative people who cherish customs and traditions.

37. Most of my favourite actors and musicians are either British or American.

38. British culture has contributed a lot to the world.

Anxiety

39. I feel uncomfortable if I have to speak in my English class.

40. It embarrasses me to volunteer answers in my English class.

41. I don't like to speak often in English class, because I am afraid that my teacher will think I am not a good student.

42. I am afraid other students will laugh at me when I speak English.

43. I think I can learn English well, but I don't perform well on tests and examinations.

44. I often have difficulty concentrating in English class.

Motivational Strength

45. If the fees for this class were increased, I would still enrol because studying English is important to me.

46. My attendance in this class will be good.

47. I plan to continue studying English for as long as possible.

48. After I finish this class, I will probably take another English course.

49. I often think about how I can learn English better.

50. I can honestly say that I really put my best effort into trying to learn English.

\section{Copyright Disclaimer}

Copyright reserved by the author(s).

This article is an open-access article distributed under the terms and conditions of the Creative Commons Attribution license (http://creativecommons.org/licenses/by/3.0/). 